ELORE (ISSN 1456-3010), vol. 18 - 2/2011.

Julkaisija: Suomen Kansantietouden Tutkijain Seura ry.

[http://www.elore.fi/arkisto/2_11/tiili.pdf]

\title{
LÄSNÄOLOA JA REFLEKSIIVISYYTTÄ
}

\section{Ammattikulttudrin tutkimus Merleau-Pontyn FENOMENOLOGIAN VALOSSA}

\author{
$\underline{\text { Miia-Leena Tiili }}$
}

\section{Ajankohtaiset aistit}

Artikkelini osallistuu keskusteluun eletyn kokemuksen ja aistihavainnon merkityksestä kulttuurien tutkimuksessa. Lähestyn kysymystä fenomenologian näkökulmasta pohtimalla ammattikulttuurin ruumiillisuutta, läsnäolon merkitystä ja kokemuksen todistusvoimaa. Ruumiillisuudella tarkoitan ihmisen kehollisuutta fenomenologiassa keskeisen eletyn ruumiin (Leib) käsitteen merkityksessä.

Aloitin Suomenlahden merivartioston ammattikulttuuria koskevan väitöstutkimuksen teon elokuussa 2007 vakuuttuneena siitä, että osallistuvaan havainnointiin liittyvä läsnäolo, moniaistisuus ja kokemuksellisuus auttavat merivartijoiden työn luonteen ymmärtämisessä (kenttätyöstä ks. Tiili 2007). Tarkastelemalla merivartiointia toimintana ja tekoina ja kiinnittämällä huomiota työn konkreettisiin puitteisiin pyrin tavoittamaan ammatista piirteitä, jotka merivartioinnin diskursiivista todellisuutta käsittelevässä pro gradu -työssäni jäivät pimentoon.

Käsitän ammattikulttuurin työntekijöiden aktiivisena orientoitumisena maailmaan ja vuorovaikutuksena sen kanssa (kulttuurista prosessina ks. Ehn \& Löfgren 2004, 12-13; Ojanen 2011, 19-21; Paaskoski 2008, 11-12, 237-241). Lähestyn merivartijan ammattia sekä kehollisena että diskursiivisena ilmiönä. Merivartijoiden toimintaympäristöt, kalusto, tehtävät ja toiminta näyttäytyvät merivartijuuden ankkuripaikkoina, joissa käsityksiä itsestä ja työstä tuotetaan ja vahvistetaan.

Liitän tutkimukseni osaksi pohjoismaisen etnologian kulttuurianalyyttistä suuntausta, johon ammennan vaikutteita fenomenologisesta filosofiasta, etenkin ranskalaisfilosofi Maurice Merleau-Pontyn (1908-1961) ajattelusta. Löysin siitä kaikupohjan tutkimusotteelleni tutustuttuani filosofian tutkija Juho Hotasen teokseen Lihan laskos (Hotanen 2008). ${ }^{1}$ Samankaltaiseen Merleau-Pontyn luentaan ja hyödyntämiseen ovat

1 Kiitän Juho Hotasta käsikirjoituksen kommentoinnista. 
päätyneet myös työn ruumiillisuutta ja sotilasammatteja tutkinut sosiologian professori John Hockey, koululiikuntaa tarkastellut etnologian dosentti Gunnel Olsson ja kuolevan rinnalla olemiseen väitöskirjassaan perehtynyt uskontotieteilijä Terhi Utriainen (Hockey \& Allen-Collinson 2009; Olsson 2010; Utriainen 1999).

Tarkastelen seuraavassa fenomenologisen filosofian vaikutuksia etnologiaan ja sen lähitieteisiin. Arvioin fenomenologisen tutkimusotteen piirteitä ja kysyn, mitä ruumiillisuuden tiedostaminen merkitsee ammattikulttuurin tutkimisen ja osallistuvan havainnoinnin kannalta. Mikä on havainnon, kokemuksen ja reflektion suhde? Entä millainen on tutkijan rooli? Päätän artikkelini pohtimalla, mitä annettavaa fenomenologialla on kulttuurien tutkimukselle. Osallistuvaan havainnointiin liittyviä tutkimuseettisiä kysymyksiä sivutaan artikkelissa siltä osin, kun ne liittyvät etnografisen kokijan ja tulkitsijan problematisointiin.

\section{FENOMENOLOGIA ETNOLOGIASSA JA SEN LÄHITIETEISSÄ}

Lingvistisen käänteen jälkimainingeissa tutkijat ovat kaivanneet uusia näkökulmia ihmisen, yhteiskunnan, kulttuurien ja taiteiden tutkimukseen. Kun kartesiolaisesta dualismista, käsityksestä hengen ja ruumiin erillisyydestä, on tieteen perustana luovuttu, on tutkijoiden mielenkiinto suuntautunut kognitiivisen ohella myös ihmisen ja fyysisen ympäristön suhteeseen, aistihavaintoihin ja kehoon. Ruumiillisuuteen ja aistittavuuteen on fokusoitu jopa siinä määrin, että voidaan puhua aistien vallankumouksesta. (Frykman \& Gilje 2003, 9, 15, 24, 30; Hockey \& Allen-Collinson 2009, 218, 220; Knibbe \& Versteeg 2008, 50; Rantala 2010, 258-259.)

Uusia tutkimuskysymyksiä on lähestytty myös fenomenologian kautta varsinkin pohdittaessa aistihavainnon, ruumiillisuuden ja aineellisen merkitystä todellisuuden jäsentämisessä ja ymmärtämisessä. Fenomenologista filosofiaa ja sen soveltamista käsittelevien julkaisujen määrä on jatkuvasti lisääntynyt sekä Suomessa että ulkomailla, ja parin viime vuoden aikana fenomenologian näkyvyys on ollut huomattava.

Fenomenologialla tarkoitetaan Edmund Husserlin 1900-luvun alussa luomaa filosofista suuntausta. Fenomenologisen filosofian kiinnostuksen kohteena on eletty todellisuus eli maailma sellaisena kuin se meille ilmenee. Se keskittyy ilmiöihin (kr. fainomena) sekä havainnon ja kokemuksen käsitteelliseen jäsentämiseen pohtiessaan, miten havainto välittää merkityksellisen kokemuksen maailmasta. Tietoisuus, kehollisuus ja eletyt kokemukset ovat siten fenomenologiassa keskeisellä sijalla. (Desjarlais \& Throop 2011, 88; Gallagher \& Zahavi 2008, 6-7.) Fenomenologia pyrkii huomioimaan "maailmasuhteemme koko kirjon" (Miettinen ym. 2010, 9-11).

Fenomenologia vaikutti voimakkaasti Alfred Schutzin sosiologiseen teoriaan ja esimerkiksi Harold Garfinkelin etnometodologiaan, jonka tavoitteena oli tutkia arkielämän vuorovaikutustilanteiden käytäntöjä. Antropologian ja sosiologian aloilla on sittemmin kehitetty muiden muassa kulttuurista fenomenologiaa, fenomenologista etnografiaa, fenomenologista sosiologiaa ja eksistentiaalista antropologiaa. Suuntauksia yhdistää kiinnostus ihmisen ja häntä ympäröivän maailman suhteeseen sekä pyrkimys tarkastella oman tieteenalan kysymyksenasetteluja fenomenologisen filosofian avulla 
(tutkimushistoriasta ks. Desjarlais \& Throop 2011, Katz \& Csordas 2003, Overgaard \& Zahavi 2009).

Ruotsalaisen etnologian saralla ensimmäisenä fenomenologisvaikutteisena tutkimuksena pidetään Lena Gerholmin vuonna 1985 valmistunutta väitöskirjaa Projektkultur och kulturprojekt, jossa selvitetään Ruotsin valtion kulttuuriprojektin vaikutuksia kansalaisten arkeen ja kokemuksiin (tutkimushistoriasta ks. Frykman \& Gilje 2003, 20-23; Hansson 2010, 5-7). Suomessa fenomenologiset vaikutteet ovat varsin verkkaan löytäneet tiensä tutkimuksen ja tieteellisen kirjoittamisen tasolle, ja fenomenologinen etnografinen tutkimus on ollut kaikilla tieteenaloilla verrattain vähäistä viime vuosiin saakka. Poikkeuksena mainittakoon Terhi Utriaisen väitöskirja Läsnä, rïsuttu, pubdas (1999). Merleau-Pontyn fenomenologia ja filosofi Sara Heinämaan ruumiinfenomenologiaa käsittelevät tutkimukset ovat keskeisellä sijalla Utriaisen tarkastellessa kuolevan rinnalla olemisen, kuolettamisen, käytäntöjä ja merkityksiä.

Hiljattain filosofian alalla on julkaistu fenomenologian perusteita selvittäviä ja uusia tulkintoja tarjoavia teoksia, ja innostus on tarttunut niin ikään kulttuurien tutkimukseen (Miettinen ym. 2010; Pöysä ym. 2010). Fenomenologian suosion voidaan olettaa kasvavan nopeasti tutkimuskirjallisuuden lisääntyessä.

\section{KultTUURIN RUUMilllisuUs}

Ihmisen ja maailman välitöntä, käytännöllistä ja reflektoimatonta vuorovaikutusta kuvataan fenomenologisessa kirjallisuudessa elämismaailman (Lebenswelt, lifeworld) käsitteellä. Husserlin mukaan ihminen suhtautuu maailmaan luonnollisella asenteella (natural attitude), jolloin asiat ovat hänelle puhtaina ja sellaisinaan. Luonnollinen asenne on arkiasenteemme, jossa asiat näyttäytyvät itsestäänselvyyksinä. (Frykman \& Gilje 2003, 36-38; Pulkkinen 2010, 29.) Merleau-Ponty puhuu tästä havaintouskona: ajattelun, tietämisen ja olemassaolon lähtökohtana on havaitseminen ja usko siihen, mitä havaitsemme (Hotanen 2008, 14-16).

Fenomenologian näkemykset ihmisen maailmasuhteen luonteesta ovat kulttuurien tutkimuksen kannalta mielenkiintoisia. Kulttuurin käytännöllinen, kehollinen ja toiminnallinen ulottuvuus on huomioitu tutkimuksissa pitkään, ja inhimillistä toimintaa on pyritty tarkastelemaan suhteessa artefakteihin tai sen materiaaliseen kontekstiin. Esimerkiksi professorit Nils Gilje ja Jonas Frykman ovat todenneet, ettei kulttuuri löydy substantiivista vaan verbistä. Kulttuuri on aktiivista ja sisältää sekä subjektin että objektin. Tutkimuskohteina eivät ole teksti tai matka itsessään, vaan lukeminen ja matkustaminen. Autoa voi tutkia esineenä, mutta autolla ajaminen tarjoaa mahdollisuuksia toisiin tulkintoihin (Frykman \& Gilje 2003, 40-41, 46-48). Aineellinen ja aistillinen on huomioitava toiminnan ja ajattelun alkupisteenä (Ehn \& Löfgren 2004, 97; Hockey \& Allen-Collinson 2009, 220-221; Ojanen 2011, 54).

Professori John Hockey on huomauttanut, että sosiologian ruumiillisuusteoriat sivuuttavat usein työtä tekevän, eletyn ruumiin ja sen aistillisuuden. Kuitenkin lukuisissa ammateissa ammattitaito muodostuu erityisestä tavasta käyttää kehoa tai aisteja: ammatillista osaamista on esimerkiksi kyky liikkua tai koskettaa tietyllä tavalla tai nähdä 
Miia-Leena Tiili: Läsnäoloa ja refleksiivisyyttä

tai kuulla oikeita asioita. Ammatteihin myös sosiaalistutaan kehollisten prosessien kautta esimerkiksi työtapojen opettelun yhteydessä. Hockey pohtii aistien merkitystä sotilaiden työssä ja toteaa fenomenologian olevan antoisa näkökulma työtä tekevän kehon tutkimiseen. (Hockey \& Allen-Collinson 2009, 217-220, 232-233.)

Etnologi Stig Grundvall puolestaan tarkastelee väitöstutkimuksessaan moottoripyöräjengin kulttuuria ja kuvailee tilannetta, johon liittyy voimakas yhteisöllisyyden kokemus. Tutkija kertoo automatkan tiiviistä tunnelmasta, kuumuudesta ja kovaäänisestä yhteislaulusta, joka saa itsen rajat hälvenemään ja ryhmän muuttumaan yhdeksi. (Grundvall 2005, 173-175.) Lähestymistapa osoittaa kouriintuntuvasti, etteivät toveruus ja yhteisöllisyys ole pelkkiä sosiaalisia konstruktioita, vaan kehollisia toimintoja ja aistimuksia, jotka jättävät kokijaansa jäljen.

\section{Aistihavainnon todistusvoima}

Koska elämismaailma on aineellinen ja aistittava, ovat tutkijat kiinnostuneet siitä, miten aistihavainnon kautta välittyvää tietoa voidaan käyttää tutkimuksessa. Pohjoismaisen kulttuurianalyysin piirissä tutkijat ovat huomioineet fyysisen ympäristön merkityksen ja pyrkineet ennakkoluulottomasti hyödyntämään aistihavaintoja lähdeaineistona, vaikka moniaistista tutkimusotetta ei yleensä olekaan liitetty fenomenologiseen traditioon. (Ehn \& Löfgren 2004, 107, 137-140.) Toisaalta fenomenologia on mainittu potentiaalisena suuntauksena, sillä sen on nähty sopivan etnologian kokemusperäisyyteen ja arkeen liittyviin tutkimusaiheisiin. Tällöin fenomenologiasta on haettu oikeutusta arkielämän käytännönläheiselle tutkimukselle, ja käsite rinnastuu empirismiin. (Frykman \& Gilje 2003, 15-16, 19-20; Åström 2005, 25, 34.)

Osa tutkijoista on pyrkinyt hahmottelemaan fenomenologista menetelmää kehollisten kokemusten analysoimiseksi ja saavuttaakseen ensikäden (reflektoimatonta) tietoa maailmasta. Fenomenologisesti orientoituneilla tutkijoilla, kuten filosofeilla, on erilaisia käsityksiä siitä, missä määrin ja millä keinoin tämä onnistuu, mutta tavoitteena on joka tapauksessa ollut muodostaa fenomenologiaan pohjautuva havaitsemisen ja tulkitsemisen tapa, joka mahdollistaisi aistihavaintojen systemaattisen käytön lähdeaineistona. (Frykman \& Gilje 2003, 8-9; Hansen 2003, 164-165; Hjemdahl 2003, 134; Rantala 2010, 261.)

Kokeiluja puhtaan havainnon tai kokemuksen tavoittamiseksi luonnollisen asenteen kautta ei kuitenkaan ole pidetty onnistuneina. Asioita itseään ei ole tavoitettu, niitä ei ole pidetty informatiivisina, tai ennakko-oletuksista vapautuminen on osoittautunut mahdottomaksi. Lisäksi on todettu, etteivät aistihavaintojen ja koetun kuvailu riitä luomaan kokonaiskäsitystä kulttuurista, yhteisöstä tai ilmiöstä. Fenomenologisesti orientoituneet tutkijat ovat näin toisinaan kyseenalaistaneet fenomenologisen metodin mielekkyyden. (Hansen 2003, 151-153, 155-156; Knibbe \& Versteeg 2008, 48, 55-57, 61; Rantala 2010, 280.)

Etnologian, sosiologian ja antropologian alalla fenomenologisia suuntauksia on kritisoitu etenkin fenomenologian yksilökeskeisen näkökulman takia. Koska tutkimuskohteena on ihmisen ja maailman suhde, nousee kokeva yksilösubjekti keskeiseen ase- 
maan. Lähestymistavan on epäilty laiminlyövän ilmiöiden yhteisöllisten ja kulttuuristen rakenteiden tarkastelun ja irrottavan asiat niiden historiallisesta kontekstista. (Alftberg 2010, 36; Hansson 2010, 5-6, 31; Knibbe \& Versteeg 2008, 59-60.) Kärkkäintä arvostelua ovat esittäneet marxilaiset ajattelijat, jotka ovat leimanneet fenomenologisen tutkimuksen konservatiiviseksi ja kritiikittömäksi: fenomenologia ei huomioi riittävästi yhteiskunnan sosioekonomisia ja poliittisia valtarakenteita, vaan tarkastelee maailmaa porvarillisen individualismin hengessä. Kriitikoiden mukaan fenomenologia vahvistaa status quota ja oikeuttaa alistussuhteiden olemassaolon, vaikka tieteen tulisi pyrkiä epäoikeudenmukaisuuksien korjaamiseen. (Desjarlais \& Throop 2011, 95; Overgaard \& Zahavi 2009, 111-113.)

Fenomenologiaa kohtaan esitetty kritiikki ei kuitenkaan aivan tavoita kohdettaan. Kirjallisuuteen luotu katsaus osoittaa, että tutkimusten viittaukset fenomenologiseen filosofiaan ovat usein vähäisiä. Alkulähteitä ei aina käytetä, eivätkä tutkimusaiheet tai menetelmien perusteet nouse fenomenologian traditiosta. (Ks. myös Katz \& Csordas 2003, 277; Olsson 2010, 9.) Fenomenologian keskeisiä lähtökohtia saatetaan hyödyntää irrallisina teeseinä, jolloin analyysin anti jää kapeaksi. Toisinaan fenomenologian perusteita ei ole ymmärretty tai käsitteistön määrittely on sekavaa. (Esim. Knibbe \& Versteeg 2008; Silvén 2004, 124, 128.) Epävarmuutta on sekä fenomenologiaa soveltavissa että sitä kritisoivissa tutkimuksissa.

Kulttuurien ja yhteisöjen tutkimuksen kannalta on muun muassa oleellista huomata, ettei fenomenologian tutkimuskohteena ole vain yksilö. Vaikka fenomenologian mielenkiinto kohdistuu kokevaan yksilösubjektiin, huomioi se myös yksilöiden jakaman todellisuuden ja yhteisölliset aikaansaannokset. (Miettinen 2010, 151-152.) Tavoitteena ei ole eritellä ja luetella yksilöllisiä kokemuksia, vaan hahmottaa kokemisen yleisiä piirteitä. Havaintoa ja kokemusta ei pidetä yleistettävinä, mutta niiden katsotaan kuvaavan maailmaa, jonka me yksilöinä jaamme. (Frykman \& Gilje 2003, 10-11; Gallagher \& Zahavi 2008, 19; Miettinen ym. 2010, 11; Olsson 2010, 13; Pulkkinen 2010, 43; Utriainen 1999, 50-51.)

Fenomenologian soveltamisen eräänä haasteena on fenomenologisen filosofian laajuus ja pirstaleisuus. Keskeiset ajattelijat pohtivat fenomenologian ydinkysymyksiä läpi tuotantonsa, mikä näkyy käsitteiden kehittelynä ja osin ristiriitaisuuksina. Kommentaarikirjallisuus tarjoaa lisäksi runsaasti tulkintoja, kuten reduktion ja intersubjektiivisunden käsitteiden osalta voidaan todeta. (Duranti 2010, 16-17; Pulkkinen 2010, 27-28, 34-35; Taipale 2010, 118.) Filosofian moninaisuus heijastuu luonnollisesti sitä soveltaviin tutkimuksiin (Desjarlais \& Throop 2011, 88, 92, 94-95; Gallagher \& Zahavi 2008, 6).

Viime aikoina fenomenologiaan perehtyneet yhteiskuntatieteilijät ja kulttuurintutkijat ovat oikaisseet esimerkiksi yksilökeskeisyyttä ja reduktiota koskevia virhetulkintoja ja tarjonneet tutkimushistoriallisia katsauksia. Myös fenomenologisen filosofian edustajat ovat reagoineet soveltavan tutkimuksen terminologisiin ja metodologisiin väärinymmärryksiin. Siitä huolimatta fenomenologian hyödyntämistä on pidetty mahdollisena ja suotavana, kunhan filosofisia kysymyksiä ei erehdytä pitämään käytännöllisinä tutkimusongelmina eikä fenomenologiaa sekoiteta naturalismiin. (Desjarlais \& Throop 2011, 95; Duranti 2010, 18-19, 25; Gallagher \& Zahavi 2008, 19-20, 28-29; Overgaard \& Zahavi 2009, 113.) 
Miia-Leena Tiili: Läsnäoloa ja refleksiivisyyttä

Fenomenologiasta kiinnostuneelle tutkijalle ei ole tarjolla selkeää fenomenologista teoriaa, josta ammentaa. Sen sijaan lienee hedelmällistä pohtia, mitä eri suuntaukset ja tulkinnat voivat antaa ja miten niitä voitaisiin kehittää fenomenologisen filosofian perusteita unohtamatta.

\section{FENOMENOLOGIA KRIITTISENÄ ASENTEENA}

Fenomenologian kiinnostus elämismaailmaan ei tarkoita, että luonnollinen asenne ja aistihavainto tarjoaisivat suoraa ja absoluuttista tietoa maailmasta. Fenomenologian leimallisimpia piirteitä on pyrkimys ottaa etäisyyttä naiiviin arkiasenteeseen, jotta todellisuutta voitaisiin tarkastella sellaisena kuin se havaintokokemuksessa ilmenee. Samalla halutaan välttää teoreettista spekulointia ja valmiiden ennakko-oletusten projisointia tutkittavaan ilmiöön. (Gallagher \& Zahavi 2008, 26.) Lähtökohtana on, että filosofian ja tieteen on palattava asioibin itseensä.

Uudet tulkinnat korostavat fenomenologian olevan teorian sijaan asenne tai asenteenmuutos. Se on askel taaksepäin, asenteiden neutralointia ja filosofista radikalismia, jonka tarkoituksena on kyseenalaistaa itsestään selvät käsitykset asioita itseään unohtamatta. (Frykman \& Gilje 2003, 9; Hockey \& Allen-Collinson 2009, 228-229; Gallagher \& Zahavi 2008, 22, 26; Miettinen ym. 2010, 10-12; Pulkkinen 2010, 34-35.)

Asenteenmuutoksesta käytetään nimityksiä epokhe tai reduktio. Käsitteiden sisällöstä ja reduktion mahdollisuudesta on fenomenologisessa filosofiassa tuotettu lukuisia tulkintoja. Husserl painotti reduktion merkitystä kautta tuotantonsa. Martin Heidegger puolestaan ei omaksunut reduktion ajatusta vaan korosti, ettei ennakko-oletuksettomuus ole mahdollista. Merleau-Pontyn mukaan Husserlin reduktion tärkein opetus on, että täydellinen reduktio on mahdoton. Esireflektiivinen havainto ja kokemus pakenevat niitä tavoiteltaessa. (Gallagher \& Zahavi 2008, 23-24, 27; Hotanen 2008, 52-55; Merleau-Ponty 2002 (1945), xv, 49, 71; Pulkkinen 2010, 27-29.) Reduktion kiistanalaisuudesta huolimatta pyrkimys tarkastella subjektiivista kokemusprosessia filosofisen reflektion avulla on fenomenologian ytimessä.

Fenomenologisen asenteen luonnehdinnat muistuttavat kulttuurianalyysin retoriikkaa, jossa tutkimusprosessia luonnehditaan läheisyyden ja analyyttisen etäisyyden vaihteluksi, eläytymiseksi ja irrottautumiseksi, tutun tekemiseksi vieraaksi ja tutkimuskohteen etäännyttämiseksi (Esim. Ehn 2003, 90; Ehn \& Klein 1999, 40-41, 77; Ojanen 2008, 8-9; Ojanen 2011, 62-63, 68). Kirjallisuudessa läheisyyden ja etäisyyden kuvailu on runsasta ja vivahteikasta, ja siihen sisältyy perspektiivin vaihtamista, arkiymmärryksen kyseenalaistamista, teoretisointia, uusin silmin näkemistä, yllättävien näkökulmien hakemista ja epätyypillisten kysymysten asettamista. (Esim. Ehn \& Löfgren 2004, 145, 149.) Kulttuurianalyysi käsitteenäkin viittaa erittelyyn ja pilkkomiseen.

Läheisyyden ja etäisyyden metaforaa on etnologian alalla myös kritisoitu, sillä sitä on pidetty liian lineaarisena ja yksioikoisena vastaamaan tutkimuksen teon todellisuutta (Paaskoski 2008, 15-16). Tutkimusprosessia voidaan luonnehtia monin sopivin vertauskuvin, mutta etnologinen (ja -grafinen) tietämys lähtee yhtä kaikki siitä, että analyyttisyys ja uskottavien tulkintojen tekeminen vaatii tutkijalta vaikutelmiensa ja 
tulkintojensa kyseenalaistamista sekä tutkijan ja tutkimuskohteen välisten sidosten auki punomista ja tarkastelua.

\section{REFLEKSIIVISYYDEN VÄLTTÄMÄTTÖMYYS}

Asenteenmuutoksen ja positionvaihdoksen korostaminen lähestyy ihmistieteissä tärkeää refleksiivisyyden tavoitetta. Tutkijan subjektiivisuus nähdään erottamattomana osana tutkimusta, ja tutkijan odotetaan selvittävän avoimesti rooliaan sekä vaikutustaan aineistoon ja tulkintoihin, jotta tutkimuksen pätevyyttä voidaan arvioida. Etenkin tutkimuksissa, joissa hyödynnetään osallistuvaa havainnointia ja joissa tutkijan ja tutkittavien keskinäinen kanssakäyminen on tiivistä, tutkijoilta edellytetään refleksiivisyyttä aiheelle sokeutumisen ja go native -ilmiön ehkäisemiseksi. (Hansen 2003, 161; Ojanen 2008, 2-3, 11; Snellman 2003, 56-57; Åström 2005, 29.)

Oman position ja vaikuttimien kriittistä tarkastelua kutsutaan vaihtelevasti refleksiivisyydeksi, reflektiivisyydeksi tai itsereflektioksi. Outi Fingerroos on luonnehtinut refleksiivisyyttä paikantamiseksi ja subjektisidonnaisuuden hahmottamiseksi, mikä pitää sisällään asetelman tuomisen julki tutkimustekstissä. (Fingerroos 2003.) Refleksiivisyys on itsekriittisyyttä ja tietoisuutta omasta ajattelusta (Ehn 2003, 94, 96; Ehn \& Klein 1999, 11-12). Antropologi Charlotte Aull Daviesin mukaan "reflexivity, broadly defined, means a turning back on oneself, a process of self-reference" (Davies 2008, 4).

Refleksiivisyyden tehtävänä voidaan yleisesti nähdä tutkijan epistemologisten ja ontologisten lähtökohtien sekä ihmiskuvan arviointi ja artikulointi. Tutkijan tekemät tulkinnat on kyettävä kontekstualisoimaan postmodernista teoriasumasta ja moniäänisyydestä huolimatta. (Ehn 2003, 167.) Refleksiivinen paikantaminen osoittaa, että tutkija ymmärtää kuka hän on, mitä hän on tekemässä ja mitä hänen tutkimuksensa edustaa samalla, kun hän hahmottaa (itselleen ja lukijalle) tutkimuksensa rajat (Fingerroos 2003). Refleksiivistä työtapaa ei tule sekoittaa egosentrisiin paljastuksiin, sillä refleksiivisyys ei ole päämäärätöntä tunnustuksellisuutta tai rippi. Lukijan huomio ei saisi kohdistua tutkijan henkilökohtaiseen elämään, vaan siihen, mitä teksti kertoo synnystään ja millaisia kokemuksia siihen sisältyy. (Ehn \& Klein 1999, 34, 48, 64, 79-80; Fingerroos 2003; Ojanen 2008, 10; Ojanen 2011, 65, 69.)

Kuten folkloristi Karoliina Ojanen huomauttaa, ovat refleksiiviset prosessit avainasemassa, kun tutkija irrottautuu kentästään ja työstää kokemuksiaan analyyttiseksi tiedoksi (Ojanen 2008, 11-12). Eläytymisen on nähty muuttuvan analyyttisyydeksi etenkin kirjoittamisen myötä (Ehn 2003, 123-125, 176; Ehn \& Klein 1999, 15, 39-41; Grundvall 2005, 50. Refleksiivisyys voi näin olla sekä analyyttisen etäisyyden muoto että seuraus. Analyyttinen etäisyys ei ole vain irrottautumista, position vaihtamista tai kääntymistä poispäin, vaan monipuolisilla ja eritasoisilla näkökulmilla rikastamista.

Refleksiivisyyden haasteet liittyvät paitsi rajanvetoihin, olennaisen ja epäolennaisen määrittämiseen, myös siihen, miten itsen kriittinen tarkastelu on mahdollista. Kriittisen etäisyyden ja sokaisevan läheisyyden problematiikkaa pohtivalle Merleau-Pontyn käsitys reflektion luonteesta voi olla avuksi. Merleau-Pontyn mukaan havaitsevan ja havaintoa analysoivan minän välillä on etäisyys. Voin tarkastella kokemustani ref- 
lektoimalla, mutta alkuperäinen reflektoimaton pakenee reflektion lähestyessä sitä. Samalla tavoin kuin koskettavan ja kosketetun ruumiin tai katsovan ja katsottavan ruumiin välillä on ero, ei myöskään ajattelu tavoita kokemusta sellaisenaan. Reflektoiva ja reflektoitu ovat siis erillään, ja reflektoivalle minälle reflektoitu minä on toinen. (Hotanen 2008, 52-55, 124-125; Merleau-Ponty 1968, 147-148; Merleau-Ponty 2002 (1945), 49, 103-104, 230-231.)

Merleau-Ponty näkemys reduktiosta ja reflektiosta ei silti sivuuta yksilön kulttuurisia ja yhteisöllisiä sidoksia. Merleau-Ponty ei väitä, että reflektio irrottaisi yksilön luonnollisesta asenteesta tai kulttuurisista käsityksistä ja tarjoaisi ongelmattomasti pääsyn puhtaisiin, alkuperäisiin kokemuksiin. Täydellinen vapautuminen uskomuksista ja täydellinen reduktio ovat hänen mukaansa mahdottomia. (Hotanen 2008, 52-53; Merleau-Ponty 2002 (1945), xv, 213-214.)

Fenomenologia kyseenalaistaa tieteen objektiivisuuden ja toteaa sen muodostuvan tiedostavien yksilöiden yhteisöllisen toiminnan tuloksena. Havainto on aina jostakin, ja havaitsija havaitsee omasta näkökulmastaan. Havaitsijan keho on hänen nollapisteensä suhteessa maailmaan: ihminen elää ja kokee kehollaan ja kehostaan käsin. Katse (tai havainto) ei-mistään ei siis ole mahdollinen. Samalla tietoisuus näyttäytyy rajallisena ja epätäydellisenä. Koska havaitsen omasta näkökulmastani, en koskaan tavoita koko maailmaa kerralla. (Desjarlais \& Throop 2011, 89-90; Gallagher \& Zahavi 2008, 8, 18-19, 40; Hotanen 2008, 85-87; Merleau-Ponty 2002 (1945), 71, 77-79, 95.) Lisäksi huomion kiinnittymisen prosessi ja sattuma vaikuttavat siihen mitä havaitsemme. (Gallagher \& Zahavi 2008, 28; Merleau-Ponty 2002 (1945), 30-32.) Havainnolla ja kokemuksella on siten temporaalinen ja spatiaalinen, ajallinen ja tilallinen, luonne (Gallagher \& Zahavi 2008, 7). Fenomenologia tukee tutkimuksen refleksiivisyyttä muistuttamalla tutkijan tietämisen rajallisuudesta ja tilannekohtaisuudesta.

\section{FENOMENOLOGINEN METODI}

Fenomenologiaa hyödyntävässä tutkimuksessa ei useinkaan määritellä tarkasti fenomenologista menetelmää. Fenomenologisen työtavan kehittelyä ei helpota fenomenologian yksilöfokus, jolla on vaikutuksensa tutkijan rooliin: tutkijalla on paljon vapautta luoda tutkimusmetodinsa, mutta vähän keinoja varmistua valintojensa onnistuneisuudesta. (Olsson 2010, 14-15.)

Tutkijoiden keskuudessa vallitsee yksimielisyyttä siitä, ettei fenomenologiaa tule kaventaa yksinkertaistetuksi tekniikaksi tai prosessiksi, jonka noudattamisen oletettaisiin johtavan fenomenologiseen lopputulokseen (Frykman \& Gilje 2003, 9; Hockey \& Allen-Collinson 2009, 228-229). Fenomenologiaa ei ole kokemusten luetteleminen. Sen sijaan sen refleksiivinen kuvaileminen, miten maailma meille kokemuksissa ilmenee, on tärkeä osa fenomenologiaa. (Gallagher \& Zahavi 2008, 26.)

Jack Katzin ja Thomas Csordas mainitsevat fenomenologisen antropologian piirteinä asiat itsensä tutkimuskohteina, tutkijan osallistumisen ja ruumiillisuuden tutkimuksen. Se on elämismaailman rakenteiden kriittistä tutkimista erilaisin osallistuvaan havainnointiin kuuluvin keinoin. (Katz \& Csordas 2003, 284-285.) John Hockeyn fenomenologinen ote perustuu aistihavaintojen ja konkreettisen, kehollisen toiminnan 
Miia-Leena Tiili: Läsnäoloa ja refleksiivisyyttä

monivivahteiseen kuvailuun, joka täydentää työtä tekevän kehon teoreettista analyysiä tuomalla siihen ruumiillisen ulottuvuuden. (Hockey \& Allen-Collinson 2009, 218, 232-234.)

Fenomenologit Søren Overgaard ja Dan Zahavi puolestaan luonnehtivat fenomenologisen sosiologian tehtäväksi käytännöllisen ja koetun elämismaailman kuvailemisen. Heidän mukaansa fenomenologisen sosiologian olennaisin sanoma on, ettei yhteisöllistä elämää ja ilmiöitä voida tarkastella, ellei yksilöiden osallisuutta ja toimijuutta oteta huomioon. (Overgaard \& Zahavi 2009, 113.)

Fenomenologinen tutkimus voi alkaa siitä, ettei tutkimuskohdetta määritellä, vaan tarkastelu lähtee kokemuksesta (Gallagher \& Zahavi 2008, 6). Tämä sopii hyvin etnologian heuristiseen otteeseen. Kyseenalaistavan ja ihmettelevän otteensa takia fenomenologialla on yhtymäkohtia kulttuurianalyyttiseen lähestymistapaan, kuten edellä esitettiin. Kulttuurianalyysin konventionaalisten dikotomioiden ja käsiteparien (yhteisöllisyys - yksilöllisyys, lokaali - globaali jne.) käyttöön on fenomenologian valossa silti suhtauduttava harkiten, jotta vieraiden piirteiden projisoinnilta tutkimuskohteeseen vältytään. Käsiteparit voivat toki olla kuvaavia, mikäli ne muotoutuvat tutkimuskohteesta käsin.

Etnologian, antropologian ja sosiologian tutut metodit luovat pohjan fenomenologisten vaikutteiden hyödyntämiselle. Tutkijan subjektiivisuutta ja osallisuutta hyödyntävä tutkimusote on ominainen useimmille etnografisille tutkimuksille tutkijoiden käyttäessä kehoaan, empatiakykyään ja älyllistä herkkyyttään aineistonkeruussa ja aineiston analysoinnissa. Fenomenologia vahvistaa nämä metodologiset lähtökohdat eikä rajoita tutkijan itsenäisyyttä menetelmien ja lähteiden luomisessa. (Hockey \& Allen-Collinson 2009, 228-229; Katz \& Csordas 2003, 278, 280.)

Vapauden myötä tutkijan vastuu painottuu. Gunnel Olsson onkin korostanut tutkijan itsetuntemuksen merkitystä osana vastuun kantamista. Oman position, esiymmärryksen ja tietämyksen kriittinen reflektointi on erottamaton osa fenomenologista tutkimusta. (Olsson 2010, 15.)

\section{Merleau-Pontyn fenomenologia ammattikult'tuUrin TUTKIMUKSESSA}

Omassa tutkimuksessani Maurice Merleau-Pontyn havainnon fenomenologia ja uusi ontologia tarjoavat näkökulmia sekä merivartijoiden ammattikulttuuriin ilmiönä että osallistuvaan havainnointiin menetelmänä. Merleau-Pontyn filosofiassa kehollisuus, olemassaolo, kokemus ja tietäminen kietoutuvat toisiinsa. Hänen mukaansa maailma ei ole se, mitä ajattelen, vaan se, minkä elän. (Hotanen 2008, 20-21; Hotanen 2010, 134-135; Merleau-Ponty 2002 (1945), xviii, 94, 173, 177; Merleau-Ponty 2004 (1948), 56.)

Ihminen on maailmassa kehonsa kautta. "The body is our general medium for having a world. [...] To be a body, is to be tied to a certain world [...]; our body is not primarily in space: it is of it.” (Merleau-Ponty 2002 (1945), 169, 171.) Aistiminen on näin perustava suhteemme olemiseen. Meidän on kiinnityttävä aistittavaan maailman, 
jotta se avautuisi meille. (Merleau-Ponty 2002 (1945), xi-xii, xix; Hotanen 2008, 67, 84-85, 138.) Hotanen muotoilee Merleau-Pontyn lähtökohdan:

\begin{abstract}
"Maailma on minulle oman ruumiini kautta, ja siksi ruumis ei voi olla vain objekti maailmassa. Ruumis ei ole tietoisuuden kohde, vaan tietoisuuden perusta: havaitseminen ei ole vain ajatus havaitsemisesta, vaan ajattelua edeltävä ruumiillinen side maailmaan ja toisiin.” (Hotanen 2008, 10, 84-87.)
\end{abstract}

Merleau-Pontyn filosofiassa huomio ei kiinnity puhtaasti yksilöön tai ympäristöön, vaan näiden yhtymäkohtaan. Hän viittaa maailman lihaan ja asioiden kudokseen, johon kaikki maailmassa kiinnittyy. Ruumiin ja maailman suhdetta hän luonnehtii kiasmaksi. Ne kietoutuvat yhteen, ovat vuorovaikutuksessa ja edellyttävät toisiaan, mutteivät muutu yhdeksi ja sulaudu toisiinsa. Subjektin ja maailman välillä on aina myös etäisyys ja ero. (Hotanen 2008, 98-100, 128-129; Hotanen 2010, 134, 141; Merleau-Ponty 1968, 133-134, 138, 146.)

Merleau-Pontyn fenomenologiassa olemassaolo on kehollista ja vuorovaikutuksellista. Näin myös työnteon kulttuuri ja ammattilaisuus rakentuvat ihmisen ja maailman suhteessa. Ammattikulttuuri on siis yksilön sekä häntä ympäröivän yhteisön ja toimintaympäristön yhteenkietoutumista ja yksilön tulkinta tästä: se rakentuu ja tulee eletyksi merivartijan ruumiillisessa suhteessa alukseen tai passitarkastuskoppiin, hänen liikkeessään suhteessa asiakkaaseen, työtovereiden välisessä etäisyydessä tai läheisyydessä, virkapuvun vaikutuksessa kantajansa olemukseen tai tavoissa, joita siirtymiseen kodin ja työpaikan välillä liittyy.

Osallistuvassa havainnoinnissa otan tutkijana osaa tähän ammatilliseen ja kulttuuriseen elämismaailmaan. Havaintoni ja kokemukseni kumpuavat yhteisestä viitekehyksestä, jota tulkitsin oman kehoni ja henkilöhistoriani kautta. Etnografisen kenttätyön myötä ammattiryhmän todellisuudesta eivät enää todista vain toisten lausumat, vaan myös omat aistimukseni, tunteeni ja kokemukseni.

\title{
HeTKI MERELLÄ
}

Kenttätyövihkoni sivulla on kirjoitus, josta en saa selvää. Kynän jälki on paikoin levinnyt paperin kastuttua. Rivit kulkevat päällekkäin, kirjaimet eivät ole tunnistettavissa eivätkä sanat hahmotu. Sisällötön suttu harmittaa yrittäessäni muistella, mihin se liittyi.

Istuimme elokuisena yönä nopeassa kumiveneessä ja odotimme. Pimeydestä kuului lähestyvän veneen ääni. Lyhyitä käskyjä, muistiinpanovälineet taskuun, vene keinui, sireenin ääni ja ärjyvät koneet, pysähdys. Merivartioston hälytystehtävä päättyi odotetusti ruorijuopumusepäilyyn.

Rivit piirtyivät päällekkäin, koska oli pimeää. Teksti kertoi todennäköisesti odottamisesta ja loppui, kun odotus loppui. En voinut kirjoittaa, koska pidin kiinni veneestä. Paperi kastui, kun otin vihkon esiin märin käsin. - Kirjoitan huomiot punakynällä marginaaliin, enkä enää kaipaa kadonneita sanoja. 
Miia-Leena Tiili: Läsnäoloa ja refleksiivisyyttä

Jo kenttätyövihkojen ja merkintöjen ulkonäkö on itsessään informatiivinen. Kirjoittaminen on hetkittäin ollut hankalaa tai mahdotonta, ja kiireellisistä tehtävistä on ehditty kirjaamaan vain yksittäisiä tukisanoja. Runsaat, pohdiskelevat muistiinpanot on puolestaan tehty hetkinä, jolloin työn rytmi on ollut verkkainen.

Kuvailen työn tiloja, tuoksuja ja ääniä sekä tehtävien ja tilanteiden vaikutuksia itseeni ja toisiin. Kerron, miltä virkapuku ja varustevyö tuntuvat ja haisevat, miten asiakkaiden läsnäolo muuttaa eleitä ja asentoja, miten yövuorossa valvominen puuduttaa jäsenet, hidastaa liikkeet ja tekee ajattelun jähmeäksi ja kuinka koti-ikävä kaihertaa sydänalassa ja pistelee iholla. Yksittäiset havainnot eivät osoita minulle merivartioinnin olemusta, mutta kokemusten tarkastelu kertoo jotakin siitä, millainen merivartijoiden maailma on.

Merleau-Pontyn ajattelun perusteella tutkijan kokemuksia voidaan pitää ammatin todellisuudesta todistavana lähdeaineistona sen sijaan, että kuvailut toimisivat vain tutkimustekstin kuvituksena, henkilökohtaisena ripittäytymisenä tai etnografisena päänahkana, todisteena "siellä olosta". Omakohtaisen kokemisen myötä myös haastateltavien sanojen merkitys tihentyy. Samalla herää kysymys, miten omat havainnot suhteutuvat muiden kuvaamiin kokemuksiin. Kenen kokemuksista tutkija lopulta kirjoittaa?

\section{Minä Ja TOINEN SAMASSA MAAILMASSA}

Minän ja toisen suhde on pohjimmiltaan filosofinen kysymys, mutta tietoteoreettisista syistä sitä on tarpeellista sivuta. Dosentti Kjell Hansen toteaa itsen ja toisen eroa pohtiessaan, että tutkijan kuvittelu- ja empatiakyvyllä on rajansa, eikä tutkija tietenkään voi olla toinen ihminen. Hansen huomauttaa kuitenkin, ettei tutkijan ja tutkittavien välisiä eroja ole syytä liioitella. Tarkastelun lähtökohdaksi voidaan erilaisuuden sijaan ottaa myös kokemusten mahdollinen samankaltaisuus. (Hansen 2003, 161.)

Kokemisen ja olemassaolon yhteisöllistä ulottuvuutta tarkastellaan fenomenologiassa intersubjektiivisunden käsitteen avulla. Intersubjektiivisuus tarkoittaa pelkistetyimmillään ihmisen tietoisuutta toisista samassa maailmassa. Sillä viitataan myös itsen ja toisen suhteeseen, vuorovaikutukseen, ymmärrykseen itsestä osana yhteisöä ja kykyyn asettautua toisen asemaan. (Desjarlais \& Throop 2011, 91; Taipale 2010, 118-120.) Subjektiivinen kokemus sisältää aina intersubjektiivisen elementin, sillä kokeva subjekti on henkilöhistoriansa kautta kiinnittynyt yhteisöllisiin ja kulttuurisiin viitekehyksiin, jotka vaikuttavat hänen tulkintoihinsa. Kulttuurinen maailma on osa elämismaailmaa. (Duranti 2010, 18; Pulkkinen 2010, 38.) Yhteisöllisyyden ja kulttuurisen aspektin tiedostaminen on ominaista etenkin Schutzin ja Merleau-Pontyn ajattelulle.

Merleau-Pontyn tulkinta intersubjektiivisuudesta ja aistittavuuden synergiasta on kiehtova. Hänelle intersubjektiivisuus on ensisijaisesti ruumiiden välistä. Olemme lähtökohtaisesti erillään mutta yhteisessä maailmassa, jossa kommunikoimme ja otamme osaa samaan läsnäoloon. (Hotanen 2010, 146-148.) Koska havaitsen kehostani käsin, on jokin aina sellaisena kuin se minulle on, ja havaintoni perustuu siihen, miten minä kykenen havaitsemaan. Ihmisen yksilöllinen keho on aukeama toiminnalliseen kenttään. (Frykman \& Gilje 2003, 11; Hotanen 2008, 86-87; Merleau-Ponty 2002 (1945), ix; Olsson 2010, 13.) 
Synergia syntyy siitä, että minun asiani ja toisen asia, minun näkökulmani ja hänen näkökulmansa, muodostavat yhden toden asian. Samalla tavoin ihminen todentuu ja tulee itselleen ja toiselle näkyväksi toisen kautta. Emme kyseenalaista toisiamme, vaan teemme toisemme katseessa ja vuorovaikutuksessa. Ihminen on ihmisen peili. (Hotanen 2008, 114-116, 120-122; Merleau-Ponty 1968, 142-143; Merleau-Ponty 2002 (1945), 215.)

Minä tutkijana ja havaitsijana olen siis toinen kuin tutkittavani. En pääse kokemaan voiton huumaa voimankäyttökoulutuksessa painitatamilla järkälemäisen merivartiomiehen voittamisesta, enkä liioin voi kokea isyyden onnea. Voin kuitenkin tuntea helpotusta yövuoron päättyessä sekä tunnistaa itsessäni ja muissa saman valpastumisen hälytyspuhelimen soidessa. Voin iloita kotiinpaluusta töiden jälkeen. Erilaisuuden rinnalla on samanlaisuutta, sillä jaamme saman maailman.

Charlotte Aull Davies tekee osuvan huomion: koska identiteettiprosessin tiedetään olevan päättymätön ja vuorovaikutteinen, jättää kenttätyö väistämättä jälkensä myös tutkijaan. Kokemusten reflektointi ja vaikutteiden jäljestäminen itsestä paljastaa siten aina jotakin myös tutkimuskohteesta ja tutkittavista muista. (Davies 2008, 25-26. Ks. myös Ehn \& Klein 1999, 30.) Vastaavasti Utriainen pohjaa tutkimuksensa fenomenologiseen lähtökohtaan, että maailmassa oleminen on intersubjektiivista ja vuorovaikutteista olemista ruumissubjektina toisten ruumissubjektien keskellä. Hän tulkitsee kuolevan rinnalla olemista merkityksellisenä asentona osin oman kehonsa ja kokemuksensa kautta. (Utriainen 1999, 44-48, 181-182, 195-196, 216.)

Myös Billy Ehnin ja Orvar Löfgrenin mukaan tutkija voi introspektiolla lisätä ymmärrystään toisten kulttuurisidonnaisesta toiminnasta ja yksilöllisyydestä (Ehn \& Löfgren 2004, 156). Fenomenologian näkökulmasta ensikäden kokemusten tavoittelu reflektion avulla ei kuitenkaan ole puhtaasti introspektiota. Ajatus sisäänpäin kääntymisestä johtaa harhaan, sillä fenomenologiassa ilmiöiden ulko- ja sisäpuoli kietoutuvat yhteen. Reflektio tai reduktio eivät ole jonkin maailman ulkopuolisen, mentaalin tutkimista, eikä fenomenologia irrota mieltä maailmasta tarkastelun kohteeksi. (Gallagher \& Zahavi 2008, 15, 21, 23, 26.) Fenomenologisessa tutkimuksessa pyrkimyksenä ei siis ole reflektion avulla luodata eristäytynyttä, yksilöllistä mieltä, vaan fokus säilyy yhteisessä, jaetussa maailmassa.

\section{SANALLISEN JA SANATTOMAN SUHDE}

Merleau-Pontyn mukaan reflektion tehtävänä on tuoda kokemus ilmaisuun: reflektio pukee esireflektiivisen kokemuksen sanoiksi ja tuo sen näkyväksi, muttei vaihda sitä sanotuksi. Merleau-Pontylle näkyvää maailmaa ei ole ilman kielellistä rakennetta. Hän ei siis erota kielellistä ja kulttuurista maailmaa aistittavasta maailmasta, vaan näkee kielen ja ilmaisun osana todellisuutta, maailman lihaa. Idea jää aina sanojen tuolle puolen, mutta idea tai merkitys on vain puheen kautta. (Hotanen 2008, 53, 137, 141-145; Merleau-Ponty 2002 (1945), 225, 229.) Myös etnologian saralla on esitetty, että jo kokemuksen havaitseminen on puolittain tekstiä. Havainto on muotoutuessaan tiedostettu ja kokemus ajateltu sekä kulttuurisesti jäsennelty. Kokemus on siten "embryonaalinen 
teksti”, ja kieli on kokemisen ja tietämisen väline. (Ehn \& Klein 1999, 39.)

Kulttuurien tutkimuksen näkökulmasta Merleau-Pontyn fenomenologian vahvuutena voidaan pitää sitä, että se huomioi kehollisuuden, ajattelun ja ilmaisun tasavertaisina todellisuuden ilmentyminä. Kulttuurin rakenteet nousevat aistimellisesta maailmasta, mutta muotoutuvat ihmisten tulkinnoissa ja kokemuksissa, jotka ovat yhteisöllisesti ja kielellisesti jaettuja. (Merleau-Ponty 2004 (1948), 86-87; Merleau-Ponty 2002 (1945), 225, 229.)

Kokemus voidaan luontevasti ymmärtää jäsenneltynä, kielelle ja subjektin tulkinnalle alistettuna konstruktiona. Fenomenologia ei tällöin asetu vastakkain hermeneutiikan tai diskurssianalyysin kanssa, vaan eri tutkimusotteet täydentävät toisiaan. Sanat ja merkitykset ovat edelleen oleellisia kulttuuristen ja sosiaalisten kokonaisuuksien ymmärtämisessä. (Frykman \& Gilje 2003, 35; Hansen 2003, 160; Hockey \& AllenCollinson 2009, 221, 234.)

\section{LOPUKSI}

Fenomenologiasta kiinnostuneelle kansatieteilijälle tärkein kysymys on, palvelevatko fenomenologiset vaikutteet etnologista tutkimusta. Mitä etua fenomenologista on, kun tutkimuksen tavoitteena nähdään sosiaalisten ja aineellisten ilmiöiden tutkimus ja kulttuurin piirteiden jäsentäminen?

Fenomenologia pohtii ihmisen maailmasuhdetta. Se näkee kehollisuuden olemassaolon perustana ja tarkastelee kokemusten kautta saavutettavaa tietoa maailmasta. Fenomenologiassa ihminen ei ole eristäytynyt tietoisuus, vaan ruumissubjekti toisten joukossa ja vuorovaikutuksessa ympäristönsä kanssa.

Fenomenologinen asenne voi auttaa tutkijaa tunnistamaan tutkittavan ilmiön merkityksellisiä piirteitä ja monipuolistaa analyysia. Se luo pohjaa esiymmärryksen kriittiselle tarkastelulle ja kokemusten arvioinnille yhdessä haastateltavien kanssa. Tutkimustekstissä näkemykset ja oivallukset kirjoitetaan auki muiden arvioitaviksi, jolloin tieteen itseään korjaava ja kumulatiivinen luonne toteutuu.

Fenomenologiaan liittyvä ruumiillinen elementti muistuttaa konkreettisesti tutkijan ja tutkittavien subjektiudesta. Kokevien yksilöiden erilaisuuden tiedostaminen siirtää tulkintoja kauemmas standardisoivasta ja staattisesta kulttuurikäsityksestä. Samalla kokemuksellisuuden ja kehollisuuden korostaminen vastaa osaltaan kritiikkiin, jossa osallistuvaa havainnointia verrataan tirkistelyyn. Vertaisten kokijoiden roolit tasoittavat valtasuhteita, kun tilanteessa olijat ovat yhdessä toistensa ja muiden katseen alaisia, eikä yksi katse tai kokemus ole toista arvokkaampi. Tutkimustekstissä sen tuottajalla on luonnollisesti auktoriteettiasema, jota ei pidä häivyttää näennäisesti yhteisiin kokemuksiin viittaamalla. (Knibbe \& Versteeg 2008, 60; Ojanen 2011, 61, 83-84.)

Fenomenologia voidaan nähdä tutkijan kriittisyyttä ja refleksiivisyyttä lisäävänä asenteena, joka vaikuttaa tutkimuksen tietoteoreettisena ja ontologisena viitekehyksenä. Fenomenologian soveltaminen ei mullista etnologian metodologiaa. Kuitenkin artikuloidessaan oletuksen ihmisen maailmassa olemisen ja tietämisen luonteesta fenomenologia tukee kokemuksellisuutta, moniaistisuutta ja tutkijan intuitiota hyö- 
Miia-Leena Tiili: Läsnäoloa ja refleksiivisyyttä

dyntävää tutkimusotetta. Fenomenologian avulla ei tällöin luetella aistihavaintoja, vaan kuvaillaan ja selitetään tutkittavien ja toisaalta tutkijan maailmasuhdetta. Tämä nostaa kenttätyökokemukset tutkimustekstin kuvituksen asemasta hyödyllisiksi lähteiksi. Samalla tutkijan refleksiivisyyden välttämättömyys korostuu. Tutkijan on arvioitava sitä, miten hän tietää ja miten hänen tietämisensä suhteutuu muiden tietoon.

Ihmisen ja maailman kontaktipintoja ja vuorovaikutusta pohtivana, moniaistisuudesta muistuttavana sekä kriittistä refleksiivisyyttä edistävänä suuntauksena fenomenologia on inspiroiva lisä kulttuurintutkijan työkalupakkiin. Fenomenologinen ote tukee etnologian perustehtävää.

\section{KirjallisuUs}

ALFTBERG, ÅSA 2010: Reflektioner på Kristofer Hanssons text. - Alftberg, Åsa \& Hansson, Kristofer (red.), Fenomenologins möjligheter i etnologin. Rapport fràn en nationell workshop. Lund: Lunds Universitet.

DAVIES, CHARLOTTE AULL 2008: Reflexive Ethnography. A Guide to Researching Selves and Others. London: Routledge.

DESJARLAIS, ROBERT \& THROOP, C. JASON 2011: Phenomenological Approaches in Anthropology. - Annual Review of Anthropology, 40(1). [Review in Advance 29.6.2011, online.]

DURANTI, ALESSANDRO 2010: Husserl, intersubjectivity and anthropology. Anthropological Theory 10(1-2).

EHN, BILLY 2003: Närhet och avstånd. - Ehn, Billy \& Löfgren, Orvar, Vardagslivets etnologi. Reflektioner kring en kulturvetenskap. Stockholm: Natur och kultur.

EHN, BILLY \& KLEIN, BARBRO 1999: Fran erfarenhet till text. Om kulturvetenskaplig reflexivitet. Stockholm: Carlsson.

EHN, BILLY \& LÖFGREN, ORVAR 2004: Kulturanalyser. Malmö: Gleerups Utbildning.

FINGERROOS, OUTI 2003: Refleksiivinen paikantaminen kulttuurien tutkimuksessa. - Elore 10(2) [online]. < http://cc.joensuu.fi/ loristi/2_03/fin203c.html $>$ [10.2.2011.]

FRYKMAN, JONAS \& GILJE, NILS 2003: Introduction. - Frykman, Jonas \& Gilje, Nils (eds.), Being There. New Perspectives on Phenomenology and the Analysis of Culture. Lund: Nordic Academic Press.

GALLAGHER, SHAUN \& ZAHAVI, DAN 2008: The Phenomenological Mind. An Introduction to Philosophy of Mind and Cognitive Science. London: Routledge.

GRUNDVALL, STIG 2005: Vagabond mc. Gemenskap, manlighet och marginalitet. En studie av en västsvensk bikerklubb. Nr 2005:5 Skriftserien. Institutionen för socialt arbete. Göteborg: Göteborgs universitet.

HANSEN, KJELL 2003: The Sensory Experience of Doing Fieldwork in an 'Other' Place. - Frykman, Jonas \& Gilje, Nils (eds.), Being There. New Perspectives on Phenomenology and the Analysis of Culture. Lund: Nordic Academic Press. 
Miia-Leena Tiili: Läsnäoloa ja refleksiivisyyttä

HANSSON, KRISTOFER 2010: Inledning - fenomenologins möjligheter i etnologin. - Alftberg, Åsa \& Hansson, Kristofer (red.), Fenomenologins möjligheter i etnologin. Rapport frän en nationell workshop. Lund: Lunds Universitet.

HJEMDAHL, KERSTIN 2003: When Theme Parks Happen. - Frykman, Jonas \& Gilje, Nils (eds.), Being There. New Perspectives on Phenomenology and the Analysis of Culture. Lund: Nordic Academic Press.

HOCKEY, JOHN \& ALLEN-COLLINSON, JACQUELYN 2009: The sensorium at work: the sensory phenomenology of the working body. - The Sociological Review $57(2)$.

HOTANEN, JUHO 2008: Lihan laskos. Merleau-Pontyn luonnos undesta ontologiasta. Helsinki: Tutkijaliitto.

HOTANEN, JUHO 2010: Merleau-Ponty ja ruumiillinen subjekti. - Miettinen, Timo \& Pulkkinen, Simo \& Taipale, Joona (toim.), Fenomenologian ydinkysymyksiä. Helsinki: Gaudeamus.

KATZ, JACK \& CSORDAS, THOMAS J. 2003: Phenomenological ethnography in sociology and anthropology. - Ethnography 4(3).

KNIBBE, KIM \& VERSTEEG, PETER 2008: Assessing Phenomenology in Anthropology. - Critique of Anthropology 28(1).

MERLEAU-PONTY, MAURICE 1968: The visible and the Invisible. Wild, John (ed.). Evanston: Northwestern University Press.

MERLEAU-PONTY, MAURICE 2002: Phenomenology of Perception. London: Routledge. [1945]

MERLEAU-PONTY, MAURICE 2004: The World of Perception. London: Routledge. [1948]

MIETTINEN, TIMO 2010: Fenomenologia ja sosiaalisen todellisuuden rakentuminen. - Miettinen, Timo \& Pulkkinen, Simo \& Taipale, Joona (toim.), Fenomenologian ydinkysymyksiä. Helsinki: Gaudeamus.

MIETTINEN, TIMO \& PULKKINEN, SIMO \& TAIPALE, JOONA 2010: Johdanto. - Miettinen, Timo \& Pulkkinen, Simo \& Taipale, Joona (toim.), Fenomenologian ydinkysymyksiä. Helsinki: Gaudeamus.

OJANEN, KAROLIINA 2008: Kenttäkokemuksesta tiedoksi. - Elore 15(1).

OJANEN, KAROLIINA 2011: Tyttöjen toinen koti. Etnografinen tutkimus tyttökulttuurista ratsastustalleilla. Helsinki: SKS.

OLSSON, GUNNEL 2010: Pockande uppmärksamhet - ett fenomenologiskt krav. - Alftberg, Åsa \& Hansson, Kristofer (red.), Fenomenologins möjligheter i etnologin. Rapport frä en nationell workshop. Lund: Lunds Universitet.

OVERGAARD, SØREN \& ZAHAVI, DAN 2009: Phenomenological Sociology. The Subjectivity of Everyday Life. - Jacobsen, Michael Hviid (ed.), Encountering the Everyday. An Introduction to the Sociologies of the Unnoticed. Lontoo: Palgrave McMillan.

PAASKOSKI, LEENA 2008: Herrana metsässä. Kansatieteellinen tutkimus metsänhoitajundesta. Helsinki: SKS.

PULKKINEN, SIMO 2010: Husserlin fenomenologinen menetelmä. - Miettinen, Timo \& Pulkkinen, Simo \& Taipale, Joona (toim.), Fenomenologian ydinkysymyksiä. Helsinki: Gaudeamus. 
Miia-Leena Tiili: Läsnäoloa ja refleksiivisyyttä

PÖYSÄ, JYRKI \& JÄRVILUOMA, HELMI \& VAKIMO, SINIKKA 2010: Vaeltavat metodit. Kultaneito VIII. Joensuu: Suomen Kansantietouden Tutkijain Seura.

RANTALA, JANNE JUHANA 2010: Antropologi oom-ringissä. Aistihavainto kenttätyössä. - Pöysä, Jyrki \& Järviluoma, Helmi \& Vakimo, Sinikka (toim.), Vaeltavat metodit. Kultaneito VIII. Joensuu: Suomen Kansantietouden Tutkijain Seura.

SILVÉN, EVA 2004: Bekänna färg. Modernitet, maskulinitet, professionalitet. Stockholm: Nordiska museets förlag.

SNELLMAN, HANNA 2003: Kansa tietää! - Laaksonen, Pekka \& Knuuttila, Seppo \& Piela, Ulla (toim.), Tutkijat kentällä. Kalevalaseuran vuosikirja 82. Helsinki: SKS.

TAIPALE, JOONA 2010: Intersubjektiivisuus ja normaalius. - Miettinen, Timo \& Pulkkinen, Simo \& Taipale, Joona (toim.), Fenomenologian ydinkysymyksiä. Helsinki: Gaudeamus.

TIILI, MIIA-LEENA 2007: Merivartijoiden veneessä. - Hïdenkivi 14(5).

UTRIAINEN, TERHI 1999: Läsnä, riisuttu puhdas. Uskontoantropologinen tutkimus naisista kuolevan vierellä. Helsinki: SKS.

ÅSTRÖM, ANNA-MARIA 2005: Den etnologiska forskningsprocessen - en djupdykning i mentala och materiella sfärer. - Korkiakangas, Pirjo \& Olsson, Pia \& Ruotsala, Helena (toim.), Polkuja etnologian menetelmiin. Helsinki: Ethnos.

Filosofian maisteri Miia-Leena Tiili on kansatieteen jatko-opiskelija Helsingin yliopistossa. Hän työskentelee tutkijana Merikeskus Vellamossa Kotkassa. 